\title{
Aligning tacit knowledge and competitive advantage: a resource-based view.
}

OSOBAJO, O.A. and BJEIRMI, B. 


\title{
Aligning Tacit Knowledge and Competitive Advantage: A Resource-Based View
}

\begin{abstract}
This paper investigates the role of tacit knowledge in establishing competitive advantage using the resource-based view (RBV) theory. A framework for studying tacit knowledge, organisational performance, value creation and competitive advantage is introduced and used to analyse the oil and gas industry. The findings show that value creation and improved organisational performance play a mediating role between tacit knowledge and competitive advantage. On the one hand, the findings suggest an indirect relationship between tacit knowledge and competitive advantage, and it was instrumental when directed at creating avenues for improving organisational performance and innovations, i.e. value creation, which places an organisation in a competitive advantage position. On the other hand, organisational performance, which has a direct relationship with value creation has an indirect relationship with a competitive advantage.
\end{abstract}

Keywords: Resource-based view; tacit knowledge; organisational performance; value creation; competitive advantage; upstream oil and gas sector.

\section{Introduction}

There has been extensive use of the resource-based view theory in analysing firms' competitive position. This is because firms are perceived to possess or make use of a different set of resources and capabilities. Yet, this view is contrary to the traditional approach of organisations achieving competitive advantage through their competitive environment. The resource-based view focus on analysing a firm's resources and capabilities, which are perceived as either tangible or intangible assets (Wernerfelt, 1984). This is consistent with Barney, Wright \& Ketchen (2001) assertion that a firm's resources and capabilities are its tangible and intangible assets, including a firm's management skills, its organizational processes and routines, and the information and knowledge it controls. The traditional approach to a firm achieving competitive advantage suggests the need for a firm to give considerable attention to its competitive position and environment by pursuing a strategic position that fit between its internal environment (strengths and weaknesses) and its external environment (opportunities and threats). However, the resource-based view focus on the internal characteristic of the firm in attaining the competitive position. This is because the resources and capabilities possessed by a firm will determine its competitive position (Nath, Nachiappan \& Ramanathan, 2010). This suggests that a firm's accumulated resources and capabilities would influence what it accomplishes. Hence, more attention should be given to the firm's resources and capabilities.

Rumelt (1984, p. 557) asserted that the resource-based view supports the idea that "a firm's competitive position is defined by a bundle of unique resources and relationships". This is consistent with the argument that the resource-based view supports the firm achieving competitive advantage through it's accumulated or possessed resources and capabilities (Wernerfelt, 1984; Barney, 1991). Likewise, Adams and Lamont (2003) asserted that firms must possess the capacity to efficiently and effectively use their resources potentials to identify, develop and maintain their competitive advantage position. These views suggest that firms must identify and develop competencies such as knowledge (Wernerfelt, 1984; Grant, 1991; Barney, 1991; Conner \& Prahalad, 1996), which will be difficult for competitors to acquire or imitate. Several authors have addressed the importance of knowledge, which is perceived to hold an organisation in a synergistic advantage, not replicable in the market place (Brown \& 
Duguid, 1998; Sharkie, 2003). This is because knowledge is a valuable asset, which is more important than labour, land, or capital for any organisation (Duhon, 1998; Carneiro, 2000). Likewise, knowledge is acknowledged as power, which must be hoarded to maximise the efficient use of resources and thus maintain a competitive advantage (Stewart, 1997; Bowman, 2002; Runar Edvardsson, 2008). Knowledge is embedded as either an explicit or tacit form. Nonaka and Takeuchi (1995) referred to explicit knowledge as the knowledge that has been captured in a tangible form for re-use. Also, the authors defined tacit knowledge as the knowledge generated in the human mind and remain there for the sole use of its 'owner'. Hence, many organisations refer to their knowledge management system as an intellectual asset (Grover \& Froese, 2016). Organisations are starting to consider the importance of capturing their employees' tacit knowledge (Lecuona \& Reitzig, 2014), to attain competitive advantage position in today's aggressive and dynamic business environment. Tacit knowledge, which is possessed by individuals (i.e. employees of an organisation) is still considered to be relatively unexplored (Pathirage, Amaratunga \& Haigh, 2007; Semeon, Garfield \& Meshesha, 2015; Zaim, Gürcan, Tarım, Zaim \& Alpkan, 2015). Yet, it is crucial and instrumental to an organisation's survival.

The oil and gas industry projects often involve multi-billion investment in the development of an oilfield, construction of a deep-sea drilling rig and building of a plant (Grant, 2013). These projects are temporary endeavours with unique characteristic, and thus if knowledge capture is not managed appropriately, it will be lost forever (Brady and Davies, 2004; BlindenbachDriessen and van den Ende, 2006). However, considering the current business situation such as the need for value creation to remain competitive, it has become imperative but a significant challenge for these organisations to be creative through learning from their previous projects (Bartsch et al., 2013; Arnett \& Wittmann, 2014). Likewise, King (2009) and Mosconi and Roy (2013) have highlighted the importance of captured tacit knowledge in contributing to organisational performance. This becomes important for companies operating within the industry considering the recent downturn within the oil and gas industry as it can be a source of improved or enhanced organisational performance for organisations to remain competitive (Olaniran, Love, Edwards, Olatunji \& Matthews, 2015). These views support the assertion that tacit knowledge is increasingly an essential feature for an organisation's survival. Arguably, there is emerging importance placed on the need for companies within the oil and gas industry to capture tacit knowledge to remain competitive. Scholars such as Lee, Phan \& Chan (2005) and Beltrán-Martín, Roca-Puig, Escrig-Tena \& Bou-Llusar (2009) have investigated the relationship between a firm's human resources and competitive advantage. Yet, no study has considered the link between tacit knowledge and competitive advantage within the oil and gas industry context. Hence, this study examines the role of tacit knowledge in creating a competitive advantage for an organisation through the lens of the resource-based view.

As we explain in more detail below, the study contributes to the current understanding of knowledge as a strategic resource for organisations in two major ways: First, we extend the literature on tacit knowledge by testing a multilevel framework for understanding the relationship between tacit knowledge and competitive advantage. Second, we investigate the effects of tacit knowledge on organisational performance and value creation in creating competitive advantage position. 


\section{Conceptual Development}

Two standpoints have been identified in the literature as to where the resource-based view can be rooted. Scholars such as Penrose (1959), Schumpter (1934) and Ricardo (1817) stated that the resource-based view of the firm is rooted in organisational economics literature. In the same manner, Wernerfelt (1984), Rumelt (1984), Barney (1991) and Conner (1991) asserted that the resource-based view is rooted in the management strategy literature. The proponents of the organisational economics view support that a firm's internal resources are the primary determinant of its competitive success. Likewise, the supporters of the management strategy view stated that a firm attains competitive position through its unique corporate resources, which are rare, valuable and difficult to imitate. Despite the different approach employed by these scholars, one could argue that the resource-based viewpoints out that a firm can be seen through the resources and capabilities within its possession and/or control (Peteraf, 1993).

Wernerfelt (1984) referred to a firm as a bundle of resources and capabilities. The author went further to define resources as "anything which could be thought of as a strength or weakness of a given firm...those tangible assets which are tied semi-permanently to the firm" (p. 172). Likewise, Barney (1991, p. 101) added that an organisation's resources include "all assets, capabilities, organizational processes, firm attributes, information, knowledge, etc. controlled by a firm that enable the firm to conceive of and implement strategies that improve its efficiency and effectiveness". These views are consistent with Amit and Schoemaker (1993) definition of the firm resource as stocks of available factors that are owned or controlled by the firm. Day (1990, p. 38) defined capabilities as "complex bundle of skills and accumulated knowledge that enable firms to coordinate activities and make use of their assets". This is consistent with Amit and Schoemaker (1993) definition of capability as the firm's ability to use its resources to effect the desired result. Likewise, Teece et al. (1997) referred to the firm's capabilities as intangible assets, tangible or intangible organisational processes, which the firm has developed over some time and cannot be easily bought. Hence, scholars such as Lado and Wilson (1994), Kamoche (1996), Guest (1997) and Wright et al. (1998) concluded that the resource-based view of the firm suggests an essential approach to the relationship between organisational success and its human resource. This is consistent with Saa-Perez and GarciaFalcon (2002) assertion that the human capital possessed by a firm will potentially influence its performance.

From the foregoing, one could argue that the resource-based view suggests that individual firms will have distinctive resources and capabilities, which will consist of tangible components such as financial assets, physical assets (i.e. plant, equipment and property) and intangible elements such as technology knowhow, patent and human resources (i.e. knowledge) (Grant, 1991; Amit \& Schoemaker, 1993; Song et al., 2007). Despite the extensive analysis that has been carried out by various scholars at establishing the importance of knowledge (i.e. explicit and tacit knowledge) in creating competitive position for an organisation (Wright et al., 1994; Saa-Perez and Garcia-Falcon 2002; Lee et al., 2005; Beltrán- Martín et al., 2009), none has specifically considered how the tacit aspect of knowledge could contribute to an organisation's competitive position within the oil and gas context. This could be attributed to Spender and Scherer (2007) assertion that no organisation's resource is probably more problematic than knowledge. This is consistent with the resource-based view literature, which suggests that the main difference between knowledge and other types of resources resides in its intangibility. It is therefore, important to assess knowledge as a strategic asset of the organisation. 


\section{Knowledge, a strategic asset of the organisation}

Successful organisations have been referred to as organisations that consistently create new knowledge, disseminate it widely throughout the organisation and quickly embody it in new products and technologies (Nonaka \& Takeuchi, 1995). This is in line with Brown and Duguid's (1998) argument that knowledge holds an organisation together. These views support the assertion that knowledge is an asset, and it is essential for an organisation's survival (Carneiro, 2000; Chase, 2000). Davenport et al. (1998, p. 43) defined knowledge as "information combined with experience, context, interpretation, and reflection". Likewise, Bergeron (2003, p. 10) referred to knowledge as "information that is organised, synthesized, or summarized to enhance comprehension, awareness, or understanding". These definitions suggest that knowledge takes into consideration what is known and the context in which such known knowledge can be put into use. Walczak (2005, p. 331) added that knowledge "is any data, skill, context, or information that enables high-quality decision making and problem-solving to occur", while Groff and Jones (2012, p. 3) defined knowledge as "information combined with understanding and capability".

Knowledge is becoming the most crucial resource enabling strategic decision- making capabilities of the organisation (Kogut \& Zander,1992; de Hoog \& van der Spek, 1997). This is because it possesses the features of strategic assets (Amit and Schoemaker, 1993; Michalisin et al., 1997; Hansen et al., 1999; Drucker, 1999). These authors identified four features of a strategic asset as difficulty of imitation, imperfect mobility, durability and difficulty of substitution. This has resulted in scholars' assertion that knowledge is the fundamental basis of competition (Civi, 2000). Bollinger and Smith (2001), and du Plessis (2005) argued further that knowledge as an organisation resource influences its ability to compete and innovate. Wong and Aspinwall (2006) added that knowledge provides organisations with enhanced decision support, efficiency and innovation, which are essential to realising the strategic mission. This is in line with Daud and Yusoff (2010) assertion that knowledge as an asset enables organisations to focus on producing information, products or services to compete successfully. Hence, Van den Berg (2013) concluded that knowledge is a unique source of economic growth and value. These views are consistent with the resource-based view, which suggests that knowledge remains a strategic asset that is critical in maintaining an organisation's competitive advantage (Grant, 1996; Kogut \& Zander, 1992). Arguably, knowledge can be referred to as a strategic asset in its own right (Boisot, 1998; Goh, 2002; Evans et al., 2015).

Knowledge is perceived to be embedded as either in an explicit or tacit form (Polanyi 1967; Nonaka, 1994; O'Dell \& Grayson 1998). Hence, knowledge is either people-related or processrelated. People-related knowledge is difficult to put in words or articulate because it resides within the brain of the owner. This type of knowledge is also referred to as tacit knowledge. Nonaka and Takeuchi (1995) referred to tacit knowledge as the knowledge that is generated in the human mind and remains there for the sole use of its 'owner'. Process-related knowledge is referred to as explicit knowledge, which is the knowledge that has been captured in a tangible form for re-use. Nonaka and Takeuchi (1995) defined explicit knowledge as a formalised knowledge such as recorded videos and written documents, which often originates from a tacit knowledge 'source'. However, for this study, the focus will be on tacit knowledge. This is because an organisation is perceived to be in control of or possess knowledge-holding employees through which knowledge and value can be created for the firm (Spender, 1996). Also, scholars have asserted that tacit knowledge forms an essential element in an organisation's knowledge base and organisations are beginning to recognise their employees 
as a source of gaining competitive advantage (Black \& Synan, 1997; Harlow, 2008; Zaim et al., 2015). Hence, it becomes imperative for organisations to acknowledge the importance of their employees' knowledge to sustain their competitive advantage position (Gronhaug \& Nordhaug, 1992; Lecuona \& Reitzig, 2014).

\section{Aligning tacit knowledge and competitive advantage}

Researchers and scholars alike have demonstrated that the human element represents an essential aspect of any organisation (Prahalad, 1983). McKelvey (1983) and Flamholtz and Lacey (1981) asserted that individuals (i.e. employees) are an essential asset in developing an organisation. Ulrich $(1997 ; 1991)$ added that the human asset is vital to gaining competitive advantage. These views are consistent with Pfeffer's (1994) assertion that an organisation's employees are essential in achieving and maintaining a competitive advantage. Likewise, Wright et al. (1994), and Barney and Wright (1998) stated that those human capital resources (i.e. judgment, skills and intelligence of an organisation's employees) which play a more significant role in maintaining and sustaining competitive advantage are often overlooked. Hence, Wright et al. (2009) concluded that organisations are starting to accept that the human element plays a crucial role in their performance by providing a competitive advantage. Competitive advantage has been described by Porter (1985) as an organisation's ability to outperform its competitors. This is consistent with the resource-based view approach to competitive advantage as a means through which an organisation creates value in a different way that is difficult and/or rare for competitors to replicate (Barney 1995; Foss, 1997; Teece et al., 1997)

Wright et al. (2001) stated that tacit knowledge is the individual employee's knowledge, which organisations transform into intellectual capital to attain a competitive advantage position. Pathirage, Amaratunga \& Haigh (2007) referred to tacit knowledge as a crucial factor affecting an organisation's ability to remain a competitive position. This is consistent with Kruger and Johnson (2011) assertion that tacit knowledge is recognised as primary sources of competitive advantage of firms. Suppia and Sandhu (2011) added that tacit knowledge is known as the only distinct resource, which is crucial for any organisation to maintain its' competitive position. Hence, Arnett and Wittmann (2014), and Ranucci and Souder (2015) argued and concluded that tacit knowledge is a significant source of competitive advantage, while Kenyon and Sen (2015) added that being competitive remains the lifeblood of every organisation.

Lubit (2001, p. 167) asserted that the "difficulty of copying tacit knowledge enables tacit knowledge to be the basis of an inimitable competitive advantage". This is consistent with Berman et al. (2002) assertion that tacit knowledge is imperative for organisations to sustain competitive advantage. These views suggest that organisations should motivate employees to make use of their available knowledge. Halawi et al. (2005) argued further that tacit knowledge as a strategic asset represents a source to creating competitive advantage. Mahdi et al. (2011) added that it is essential for organisations to develop or transform individual knowledge from tacit to explicit to sustain their competitive advantage. This is in line with Kruger and Johnson (2011) assertion that tacit knowledge is recognised as primary sources of competitive advantage to boost organisation performance. Muthuveloo et al. (2017) concluded that tacit knowledge management is imperative in enhancing and maintaining organisations competitive advantage. Therefore, it is posited:

H1: There is a direct positive relationship between tacit knowledge and competitive advantage 


\section{The mediating role of organisational performance}

In contrast to the hypothesis that there is a direct positive relationship between tacit knowledge and competitive advantage, scholars have argued that an organisation can only enjoy a competitive advantage when it implements value-creating strategies and/or improved performance that is unique and different from other organisations referred to as competitors (Barney, 1991). Even though this view suggests that the authors hold contrary viewpoints, it could be a supportive approach to explaining the relationship between tacit knowledge and competitive advantage. We, therefore, consider organisational performance and value creation to play a mediating role in the relationship between tacit knowledge and competitive advantage.

Tacit knowledge is essential in achieving organisation growth and economic competitiveness (Howells, 1996). Scholars and researchers have examined the relationship between tacit knowledge and organisational performance. This is because it is perceived to plays a significant role and/or foster enhance performance (Sigala \& Chalkiti, 2007). For example, Pathirage et al. (2007) highlighted that when tacit knowledge is integrated and managed properly, it will enhance organisational performance. Likewise, Choi et al. (2010) argued that captured tacit knowledge would result in better organisational performance because it promotes better coordination and decision-making. These views are consistent with Mills and Smith (2011) argument that knowledge capabilities will improve organisational performance. Hence, it can be argued that tacit knowledge makes a significant difference in an organisation's performance (Andreeva \& Kianto, 2012). Wang et al. (2015) asserted and concluded that tacit knowledge is a critical strategy that should be considered valuable towards organisational performance.

Conversely, Koontz et al. (1980) asserted that enhance performance is imperative for organisations to gain competitive advantage. This is consistent with Wang, Bhanugopan and Lockhart (2015) argument that performance is at the core of all organisation activities as it determines the organisation's survival. Likewise, Muthuveloo et al. (2017) stated that organisational performance had been a key focus in implementing measures to ensure competitiveness. This further suggests that improved organisational performance aim to facilitate the attainment of competitive advantage. Therefore, it is posited:

$\mathrm{H} 2$ : Tacit knowledge has a significant positive influence on organisational performance $\mathrm{H} 3$ : Improved organisational performance will positively influence competitive advantage

\section{The mediating role of value creation}

Wright et al. (1994) have referred to people as a difficult resource of the organisation to replace or imitate. This is because people (i.e. organisation employees) are endowed with unique and different capacity to adapt to diverse technologies and environments. Hence, people who can create value in one context may be unable to do so in another given context. Scholars have argued that the distinctive competence of individual employees' play an important role in value creation activities (Park, 1996; Langlois \& Robertson, 1995). Likewise, Nonaka and Takeuchi (1995) stated that the transfer of tacit knowledge between individuals within a firm is primarily essential in creating value. Grant (1996) added that it is imperative to encourage value creation through optimal utilisation of existing resources such as employee knowledge, i.e. tacit knowledge for future use. This is because organisations cannot attain major innovations alone because of the dispersed knowledge resources (Moller \& Svahn, 2006). These views suggest that the process of creating value involves the efficient management of human knowledge, i.e. tacit knowledge (Chyi Lee \& Yang, 2000). 
Maskell and Malmberg (1999) stated that the origination of unique products and capabilities relies on the use of tacit knowledge. This definition suggests an innovative approach to values creation. Lowendahl et al. (2001) asserted that tacit knowledge is essential for value creation in that value is created in relation to investment in knowledge development. Hence, the main goal of knowledge management is to accumulate and leverage intangible (especially knowledge) assets to create value (Gertler, 2003). This is consistent with Dant et al. (2011) and Dant (2008) argument that different individuals come together to contribute knowledge resources to create value. This view emphasises on the importance of tacit knowledge in creating value from a co-creation point of view, i.e. the coming together of individuals to share knowledge. Kianto et al. (2014) argued further that an organisation's ability to use its intangible resources such as human knowledge, i.e. tacit knowledge effectively is crucial in creating value. Winkelbach and Walter (2015) concluded that tacit knowledge enhances an organisations awareness about how and when value can be created. Arguably, tacit knowledge is a complex resource of an organisation (Serenko \& Bontis, 2004; Darr et al., 1995), that is essential for value creation through innovation (Van der Bij et al., 2003).

Furthermore, Barney (1991, p. 102) stated that competitive advantage occurs "when a firm is implementing a value-creating strategy not simultaneously being implemented by any current or potential competitors". Tsai and $\mathrm{Li}$ (2007) added that tacit knowledge encourages organisations to create value and improve efficiency. These views suggest that the ability of an organisation to create value is a prerequisite to achieving competitive advantage. This is consistent with scholars and researchers' alike assertion that value creation is essential in attaining competitive advantage (Paswan et al., 2014; Paswan \& Wittmann, 2009; Vargo \& Lusch, 2008; Lusch et al., 2007). Therefore, it is posited:

\section{H4: Tacit knowledge has a significant positive influence on value creation}

H5: Value creation will positively influence competitive advantage

Consistent with the opinions and views of current studies, we propose a model whose central hypothesis suggests that the captured tacit knowledge of employees will enhance performance and create value for the firm. This is because such knowledge is rare, valuable, nonsubstitutable, inimitable and developed over a period of time or experience. This model also suggests that enhancing performance and creating value are prerequisite in creating a competitive advantage for the firm. This is because the mere possession of resources by a firm does not guarantee its success. Hence, this model supports the resource-based view of the firm, which asserts that a firm's resources could represent its source of competitive advantage.

Based on the theoretical review, Figure 1 illustrates the assumed conceptual framework.

\section{Insert Figure 1 here}

\section{Method}

The literature review section has helped established that organisational performance and value creation respectively play a mediating role in the relationship between tacit knowledge and competitive advantage. Using the UK upstream oil and gas sector as a case study, the research investigates how the capturing of tacit knowledge can place a company in a position of competitive advantage. 


\section{Overview of the oil and gas industry}

Pan et al. (2016) argued that the oil and gas industry is experiencing a dynamic and challenging business era in which the growth rate for oil and gas demand drops, while the supply is in surplus. This is consistent with Crompton's $(2016$, p. 10) assertion that the industry has passed through "a series of oil price shocks, followed by a stagnant decade defined by low oil prices". Rubin (2015) stated that the present situation within the oil and gas industry could result in layoffs of employees within the industry. This is in line with Kraus's (2016) assertion that the current situation within the oil and gas industry has resulted in significant unemployment. Arguably, the industry is facing a period of substantial human-capacity gaps because of energy uncertainty (Gewin, 2016). These views and opinions suggest that there is a high rate of employee turnover within the oil and gas industry.

Furthermore, Babey et al. (2016) asserted that the oil and gas industry is experiencing a shortage of skilled employees. Acheampong et al. (2016) stated further that the success of the industry's activities and operations relies on employee competence. This is in line with Badiru and Osisanya's (2016, p. 41) assertion that "the well control company is best suited to be involved in the design and implementation of the control operation, provided its personnel have the skills and capabilities to perform". Hence, the oil and gas industry's demand for employees who have the knowledge to increase efficiency and create value. Zadeh et al. (2016, p. 11) concluded that "given the complex nature of oil and gas projects, particularly in a competitive work environment, the competencies of project management personnel are seen as having a major role in overcoming the problems". These views further emphasised on the importance of human knowledge in gaining competitive advantage.

The HM Government (2013) asserted that the future of the UK Continental Shelf, which sustains high-quality jobs in the UK is likely to see smaller opportunities and a higher number of smaller upstream companies. Also, the need for higher recovery factors, an increased focus on asset integrity, more robust economics and more bespoke solutions rather than generic designs will be experienced within the industry. This suggests that appropriate human knowledge management systems should be put in place to preserve the longevity of UK Continental Shelf production over the coming decades. Therefore, a high employee turnover presents the industry with a major dilemma of losing competent individuals that possess a large amount of tacit knowledge crucial to the organisation's (and ultimately the industry's) survival. At the same time, the industry is characterised by achieving objectives through the completion of projects. Projects are characterised by being unique, one-off endeavours, complex and novel. These features lead to the assertion that projects create a large amount of knowledge and that by the end of the project this knowledge will be lost to the organisation if there is no proper mechanism to capture it.

\section{Participants}

The sample included five people working within the UK upstream oil and gas sector. Research participants were selected based on recommendation. These are people who have important and privileged information due to their position and direct involvement in project implementation. Hence, they have the responsibility of managing different people (i.e. project team). Table 1 presents the characteristic of the research participants.

\section{Insert Table 1 here}




\section{Data collection}

The research study follows a qualitative approach. Leedy and Ormrod (2001) asserted that qualitative research avails the researcher with the following opportunities:

1. Provides an insight into the nature of the phenomenon to develop new theories or concepts.

2. Understanding the nature of situations, processes, settings, systems, relationship or people.

3. It enables the test of the validity of specific theories and assumptions.

Data were collected using both secondary sources (i.e. literature review; online articles, journals, and books) and a primary source (i.e. face-to-face semi-structured interviews). The secondary sources of data collection provided the research study with the theoretical background and an outline of the key concepts within the knowledge management discipline, project performance and value creation. Hence, the topic was explored in detail to establish the foundation for the primary source of data collection. Keywords such as knowledge, knowledge management, tacit knowledge, project performance, value creation, competitive advantage, and oil and gas industry were used in the online search engines. Hence, the theoretical background offers different approaches on how to understand tacit knowledge.

Primary data collection was achieved using a face-to-face semi-structured interview method as an empirical part of the research study. Parahoo (2003, p. 307) referred to an interview as "the verbal interaction between one or more researchers and one or more respondents for collecting valid and reliable data to answer particular research questions". Those interviewed were selected through selective sampling, which aims at people within the upstream sector that are deemed to have essential and privileged information about the research area. This is in line with Sandelowski et al. (1992, p. 302) asserting that selective sampling involves a "decision made prior to beginning a study to sample subjects according to a preconceived, but reasonable initial set of criteria". Also, these are people who hold a managerial role within their respective organisations. The interview questions were designed based on previous research, the current research aim and the authors' experience. The questions specified themes flexible enough to explore research participants experience during the interview process. Each interview session lasted between 45 to 60 minutes. Research participants were guaranteed anonymity. Even though the number of interviews conducted (sample size) may not be sufficient to be fully representative of the sector of study, the issues addressed nonetheless gave significant insight into the topic under discussion.

\section{Data analysis}

For this study, the unit of analysis is the UK upstream oil and gas sector, and the targeted research participants were Managers, Senior Managers or Directors. Data collected were analysed using content analysis. Hence, no statistical analysis was provided as this will be of no added value to the research work. Data collected were thoroughly and carefully transcribed without any subtraction or addition (i.e. verbatim) to interviewees' ideas and opinion to retain the data quality, content and richness. This was sent to the research participants to review and confirm accuracy. Subsequently, transcribed interviews confirmed by research participants as accurate were read and coded independently for afterwards comparison. A start list of themes created from existing and current studies was taken on board to begin the initial coding process by the first author after reflecting and familiarizing self with the content. This concurs with 
Creswell's (2009) suggestion that reading and reflecting through data collected gives the researcher a general sense of the data collected. Likewise, this process complies with Miles et al. (2014) recommendation for analysing qualitative studies. Hence, descriptive coding was predominantly taken on board as the analysis at this stage focused more on inductive inference. The process opportune the author to understand the research themes based on research participants meaning and interpretation.

After the initial analysis (i.e. coding), the second author who is more experience conducted the second round of coding. This allowed the second author to review the proposed themes and gave feedback on their theoretical and conceptual coherence. Patton (2002) referred to this process as an essential step in assessing whether identified research themes are conceptually distinct. Also, the feedback provided information on the patterns within the data collected. This is in line with Miles et al. (2014) assertion that pattern coding is essential in explaining themes that emerge from a data, useful in explaining causes relationship, and theoretical constructs. The patterns that emerged from the data further provide insights into understanding the different hypothesis proposed within the study.

\section{Data reliability and validity}

It is essential to ensure that knowledge derived from research is evaluated based on the trustworthiness of the research findings. Hence, to foster trustworthiness, an effort was made to minimize all forms of bias while also ensuring data reliability and validity. Golafshani's (2003, p. 601) assertion, reliability and validity are "two factors which any qualitative researcher should be concerned about while designing a study, analysing results, and judging the quality of the study". However, Kirk and Miller (1986) argued that "reliability is the extent to which measurement procedure yields the same answer however and whenever it is carried out", while "validity is the extent to which it gives the correct answer". To minimise all forms of bias while also ensuring data reliability and validity, collected data for this research was enhanced using diverse techniques. Research participants were asked to review the transcribed data for accuracy. This was considered essential in mitigating against the researcher's biases. Also, the peer evaluation of the coding process by the second author to comment and provide feedback on the research findings as they emerged further mitigated researcher bias by ensuring an accurate representation of the criteria. This is consistent with Creswell (2016) assertion that a peer examination is a useful tool in fostering data reliability in qualitative studies.

\section{Results and discussion}

This research study has argued for and empirically tested a model of capturing employees' tacit knowledge in achieving competitive advantage from an oil and gas industry perspective. While not all the hypotheses formulated through the theoretical review are supported, the model that results from the research findings remain consistent with the idea that capturing employees' tacit knowledge facilitates competitive advantage through value creation and better organisational performance, which indirectly influences competitive advantage through value creation. It is worth stating that excerpts are as provided by the interviewees. As a result, the language has not been edited. The research study offers interesting and clear findings. Figure 2 presents the achieved research study findings.

\section{Insert Figure 2 here}


First, research participants' understanding of the subject matter was assessed when they were asked what they understood tacit knowledge to be. The excerpts below represent the interviewees' response to the question.

“Is something that isn't written down necessarily, but it is in somebody's head ... I guess it is typically the knowledge that is not captured by an organisation"

"Is knowledge that is not documented. Is not captured in a process. It is more inherent from people"

Even though all interviewees approached the definition of tacit knowledge differently, it is evident that all the interviewees had a good understanding of what tacit knowledge is. This further supported the use of selective sampling, which aims at actors who are deemed to have privileged and essential information about the subject matter. These views and opinions of the research participants are consistent with scholars and researchers' alike definition of tacit knowledge. For example, Polanyi (1958) referred to tacit knowledge as the knowledge held in a non-verbal form. Likewise, Pathirage et al. (2007), and Nonaka et al. (2000) defined tacit knowledge as the knowledge-based on individual experience, which they expressed in human actions through attitudes, evaluation, commitments, points of view and motivation.

Second, this research study supports the findings of scholars (e.g. Gemino et al. 2015) who found that emphasis should be placed on tacit knowledge, which is people focus as an essential determinant of performance (i.e. H2). The following excerpts support this argument.

"Considering what is going on in the industry, there is a need for organisations within this industry to focus on the human knowledge to improve their respective organisational performance".

"Haven spent fifteen years within the oil and gas industry, and I must confess that to maintain our performance as an organisation, we must give less attention to technical ability and find a way to concentrate more and make use of what our employees know".

"Is like the recent downturn resulted in a change in the way we see things within this industry. More than before, improving our organisational performance relies on the know-how of the staff. What I mean is the human knowledge of the people or staff as you may call it".

"Even though my organisation acknowledged the need to capture employee's knowledge, an effort has not been made to make use of such information to the benefit of improving the performance of the organisation".

Third, the emphasis of scholars (e.g. Kianto et al., 2014) that an organisation's ability to effectively use its intangible resources such as human knowledge is crucial in creating value (i.e. H4). Research participants stated some of the values that their respective organisations can benefit if employees' tacit knowledge is captured.

"Innovation originates from the good use of our human knowledge, so we encourage our employees to engage with each other"."Some problems are solved base on experience. New intakes need to mingle with the experience once". 
"Allow employees to be creative in framing problems by rejecting usual or obvious answer to such problem".

"It gives people an understanding of a situation or how something works. This could be through prediction".

"It will prompt employees to anticipate an outcome or occurrence"

These excerpts are in line with Johnson's (2007) assertion that tacit knowledge provides individuals with avenues to create and share their know-how knowledge. This is consistent with Winkelbach and Walter (2015) argument that tacit knowledge enhances an employee's awareness about how and when value can be created.

Fourth, our prediction that improved project performance will positively influence competitive advantage (i.e. H3) was not supported. This is because the research participants perceived improved project performance as a way of creating value. The excerpts below are in support of their assertion.

"I believe improving performance using our employees' captured tacit knowledge is a value-added"

"Improving the performance of the organisation is an important objective for all employees. The achievement of this objective will ultimately result in value creation for the organisation as a whole and our shareholders".

"We should consider either improving or enhancing performance as a means of creating value. For example, if we could finish our existing projects on or before time based on lessons learnt from experience, we will be creating value to the client".

"I don't think you can separate performance from value creation. Using my human knowledge to complete the project task on or before the scheduled time connotes that I have been able to add value to the organisation".

These excerpts further suggest an exciting finding that there is a positive relationship between organisational performance and value creation. On the one hand, it is an encouraging finding because it implies that organisational performance has an indirect relationship with competitive advantage. On the other hand, it questions the idea of if improved organisational performance is required of an organisation in achieving a competitive advantage.

Fifth, the outcome of this research study further supports our prediction that value creation will positively influence competitive advantage (i.e. H5). The research participants perceived value creation as a strong mediator between tacit knowledge and competitive advantage.

"Either creating value or value-adding is what everyone within the industry is talking about now. This can come in the form of effective cost or time management. It is obvious that our daily routine will not offer us this but the ability of all employees or members of the organisation to use their acquired knowledge well by thinking outside the box. They have to think outside the box" 
"I tell my team every day that the only way we can be competitive is to use our experience, which you referred to as human knowledge in creating value while implementing our numerous projects"

"Most of innovations you see in today environment comes from people or employees exhibiting their competences and of course the moment an organisation comes up with something innovative, and such an organisation starts to enjoy a competitive advantage over its peers"

"In my own opinion, it is difficult to separate being innovative or creating value as you may call it from enjoying a competitive advantage"

"For any organisation to enjoy competitive advantage position, such an organisation must be ready to create value, which is something unique that others have not done"

These excerpts highlight how an organisation can realise value creation from its employee's captured tacit knowledge, which is most likely to produce competitive advantage (Tantalo \& Priem, 2016).

Sixth, our prediction that capturing tacit knowledge would positively influence competitive advantage (i.e. H1) was not supported. Instead, the outcome of the research study supports the findings of Cavusgil et al. (2003), who found that tacit knowledge did not have a direct impact on competitive advantage. In our data, tacit knowledge did not impact competitive advantage directly. Still, it was instrumental when directed at creating avenues for innovations, i.e. value creation, which places an organisation in a competitive advantage position (Hooley et al., 2005; Arnett and Wittmann, 2014; Ranucci and Souder, 2015). The following excerpts from the research participants support these findings.

"I can't really make any direct connection between competitive advantage and the human knowledge, but when tacit knowledge is used in creating value or something new to the industry, competitive advantage position can be attained".

"Even though the end product of good use of tacit knowledge is positioning an organisation in a competitive advantage position, there is a lot of work to be done in getting to this position"

"I found it difficult to establish a direct link between an employee's experience or tacit knowledge as you prefer to call it and a competitive advantage. I will support the fact that good use of an employee's knowledge can be an avenue for competitive advantage but not directly create it".

"We are both aware that human knowledge is an asset for any organisation's survival. But human knowledge as an asset will not just create competitive advantage position for any organisation. It must be put to the right use for competitive advantage to be achieved".

\section{Contribution and implications}

The findings provide support for the importance of capturing employees' tacit knowledge within the upstream sector. Even though it is evident that tacit knowledge is difficult to be 
identified, managed and communicated compared to implicit knowledge, yet, it still represents a significant asset in the business environment. Tacit knowledge influences an organisation's competitive advantage position. The appropriate use of employees captured tacit knowledge facilitate value creation, such as improve organisational performance and thus promote a competitive advantage for companies within the upstream sector. It will also give room for better-informed decision making, improve efficiency, and effectiveness and innovation.

Companies within the upstream sector must encourage and promote the capturing of their employee's tacit knowledge. This can be made possible by building a culture of knowledge sharing that encourages frequent and appropriate communication among employees and as well as foster trust (Biron \& Hanuka, 2015). Management must support initiatives for development among their employees while providing an enabling environment for knowledge exchange among their employees (Chumg et al., 2015). Also, the sharing of tacit knowledge by employees within the organisation can form part of the employee's performance measurement (Ahammad et al., 2016). The more attention and importance the company attached to the sharing and/or capturing of tacit knowledge, the more the employees will see the essence of doing the needful.

Furthermore, companies need to put in place a system to identify that new knowledge has been generated and need to be captured. This could be part of a project management control system that allows feedback/feedforward sessions (Rosemann \& vom Brocke, 2015). Even though it could be challenging to determine the relevance of such information at the point of sharing or capturing, the system will help in the process of sharing and/or obtaining accurate and valuable information that support the company's current innovation. Although the time required in sharing and/or capturing tacit knowledge and the difficulty in making tacit knowledge explicit becomes a significant challenge, this can be done as part of the project management plan at the end of a milestone etc. The creation of a project management office (PMO) is recommended as a facility to store and record such information and share out as and when a new project is being initiated (Eriksson \& Leiringer, 2015). Likewise, companies can be faced with obsolete tacit knowledge information, which could make the company less competitive and can also be dealt with through the PMO. It is therefore essential for the management to encourage diverse opinions or perspectives that will serve as a check and balance for the company's application of tacit knowledge.

More so, organisations should have a feedback/feedforward system in place. The system mustn't be a blame session. This could be part of a project management control system that allows feedback/feedforward sessions. In doing this, organisations will be in a better position to ensure that the information provided is of benefit to other employees and the organisation at large. Also, there will be an opportunity to determine when such information requires an update. The system must be clearly labelled review of innovations and capturing of information. This is consistent with Song (2009) assertion that personal contact and trust between employees and the organisation at large will facilitate the effective and appropriate transfer of tacit knowledge.

\section{Limitations and future research}

Although the outcome of the research study agrees with existing research studies that there is a relationship between tacit knowledge and competitive advantage, caution should be taken in generalising the research study results to other industries. This is because the research samples selected for this research study come from within the Oil and Gas industry. Also, the study 
acknowledges that the sample size may not be fully representative of the sector under investigation. The findings from the interviews conducted suggest that locating the individual(s) with the desired or required knowledge, and then getting such individuals to share what they know willingly, is one of the toughest knowledge management challenges for an organisation. In this context, the paper poses further research questions such as, how tacit knowledge sharing will be encouraged, what mechanisms should be put in place, and how much tacit knowledge could be converted into explicit knowledge.

\section{Conclusion}

The capturing of tacit knowledge is an essential source of competitive advantage for organisations in today's competitive and dynamic business environment. This research study has established the relationship between the capturing of tacit knowledge and competitive advantage. It has further highlighted the importance of tacit knowledge in the UK upstream sector. It was established that tacit knowledge is not being shared and lost due to the high turnover of employees. There are no clear motivations for employees to share tacit knowledge. There are issues of trust and blame that must be ironed out before knowledge can be freely shared. The project management phase or milestone review as part of the project plan can facilitate the sharing of tacit knowledge the management which can be collected and systematically stored as part of the PMO. The need for further case studies on the feasibility of capturing knowledge and further research to provide evidence of the benefits of this knowledge to future projects. 


\section{References}

Adams, G.L. \& Lamont B. T. (2003). Knowledge Management systems and developping sustainable competitive advantage. Journal of Knowledge Management, 7( 2), p.142-154.

Ahammad, M.F., Tarba, S.Y., Liu, Y. \& Glaister, K.W. (2016). Knowledge transfer and crossborder acquisition performance: The impact of cultural distance and employee retention. International Business Review, 25(1), pp.66-75.

Amit, R. \& Schoemaker, P. J. (1993). Strategic assets and organisational rent. Strategic Management Journal, 14(1), 33-46.

Arnett, D.B. \& Wittmann, C.M. (2014). Improving marketing success: The role of tacit knowledge exchange between sales and marketing. Journal of Business Research, 67(3), pp.324-331.

Barney, J. (1991). "Firm resources and sustained competitive advantage", Journal of Management, Vol. 17 No. 1, pp. 99-120

Barney, J., Wright, M. \& Ketchen Jr, D.J. (2001). The resource-based view of the firm: Ten years after 1991. Journal of Management, 27(6), pp.625-641.

Barney, J.B. \& Wright, P.M. (1998). On becoming a strategic partner: The role of human resources in gaining competitive advantage. Human Resource Management (1986-1998), $37(1)$, p.31.

Beltrán-Martín, I., Roca-Puig, V., Escrig-Tena, A. \& Bou-Llusar, J.C. (2009). Internal labour flexibility from a resource-based view approach: Definition and proposal of a measurement scale. The International Journal of Human Resource Management, 20(7), pp.1576-1598.

Berman, S.L., Down, J. and Hill, C.W., 2002. Tacit knowledge as a source of competitive advantage in the National Basketball Association. Academy of Management Journal, 45(1), pp.13-31.

Biron, M. \& Hanuka, H. (2015). Comparing normative influences as determinants of knowledge continuity. International Journal of Information Management, 35(6), pp.655- 661.

Boisot, M.H. (1998). Knowledge assets: Securing competitive advantage in the information economy. OUP Oxford.

Bollinger, A.S. \& Smith, R.D. (2001). Managing organizational knowledge as a strategic asset. Journal of knowledge management, 5(1), pp.8-18.

Brown, J.S. \& Duguid, P. (2000), "Balancing act: how to capture knowledge without killing it’', Harvard Business Review, Vol. 78 No. 3, pp. 73-80.

Cavusgil, S. T., Calantone, R. J., \& Zhao, Y. (2003). Tacit knowledge transfer and firm innovation capability. The Journal of Business and Industrial Marketing, 18(1), 6-21. 
Chen, L. \& Mohamed, S. (2010), The strategic importance of tacit knowledge management activities in construction, Construction Innovation, Vol. 10 Iss 2 pp. $138-163$

Chumg, H.F., Cooke, L., Fry, J. \& Hung, I.H. (2015). Factors affecting knowledge sharing in the virtual organisation: Employees' sense of well-being as a mediating effect. Computers in Human Behavior, 44, pp.70-80.

Civi, E. (2000). Knowledge management as a competitive asset: a review. Marketing Intelligence \& Planning, 18(4), pp.166-174.

Conner, K. R. \& Prahalad C. K. (1996). "A Resource-Based Theory of the Firm: Knowledge Versus Opportunism”, Organization Science, Vol. 7, No 5: 477-501.

Creswell, J.W. and Poth, C.N., 2016. Qualitative inquiry and research design: Choosing among five approaches. Sage publications.

Creswell, J.W., 2002. Educational research: Planning, conducting, and evaluating quantitative (pp. 146-166). Upper Saddle River, NJ: Prentice-Hall.

Creswell, J.W., 2009. Research design: Qualitative and mixed methods approaches. London and Thousand Oaks: Sage Publications,

Daud, S. \& Yusoff, W.F.W. (2010). Knowledge management and firm performance in SMEs: The role of social capital as a mediating variable. Asian Academy of Management Journal, $15(2)$

Day, G. S. (1990). Market driven strategy: Processes for creating value. New York: Free Press de Hoog, R. \& van der Spek, R. (1997), “Knowledge management: hope or hype?”, Expert Systems with Applications (Guest editorial), Vol. 13 No. 1, pp. v-vi

Desouza, K. \& Evaristo, R. (2003), “Global knowledge management strategies”, European Management Journal, Vol. 21 No. 1, pp. 62-7.

Desouza, K.C. \& Evaristo, J.R. (2004), "Managing knowledge in distributed projects", Communications of the ACM, Vol. 47 No. 4, pp. 87-91.

Drucker, P. (1999). Management Challenges for the 21st Century. New York, NJ: Harper Business.

$\mathrm{Du}$ Plessis, M. (2005). Drivers of knowledge management in the corporate environment. International journal of information management, 25(3), pp.193-202.

Eriksson, P. E. \& Leiringer, R. (2015). Explorative and exploitative learning in project-based organizations: improving knowledge governance through a project management office?. Engineering Project Organization Journal, 5(4), pp.160-179.

Evans, M., Dalkir, K. \& Bidian, C. (2015). A holistic view of the knowledge life cycle: the knowledge management cycle (KMC) model. Leading Issues in Knowledge Management, Volume Two, 2, p.47. 
Flamholtz, E., \& Lacey, J. (1981). Personnel Management: Human Capital Theory and Human Resource Accounting. Los Angeles, CA: Institute of Industrial Relations, UCLA.

Girard, John P., \& Girard, JoAnn L. (2015). "Defining knowledge management: Toward an applied compendium" (PDF). Online Journal of Applied Knowledge Management. 3 (1): 120.

Goh, S.C. (2002). Managing effective knowledge transfer: an integrative framework and some practice implications. Journal of knowledge management, 6(1), pp.23-30.

Golafshani, N., 2003. Understanding reliability and validity in qualitative research. The qualitative report, 8(4), pp. 597-606

Grant, R. M. (1991). The Resource-Based Theory of Competitive Advantage: Implications for Strategy Formulation. California Management Review, 33(3): 114-135.

Grant, R. M. (1996). Toward a knowledge-based theory of the firm. Strategic Management Journal, 17: 109-122.

Grant, R.M. (2013). The development of knowledge management in the oil and gas industry. Universia Business Review, (40).

Groff, T. \& Jones, T. (2012). Introduction to knowledge management. Routledge.

Guest, D.H. (1997). 'Human Resource Management and Performance: A Review and Research Agenda', International Journal of Human Resource Management, 8: 263-76.

Halawi, L.A., Aronson, J.E. and McCarthy, R.V., 2005. Resource-based view of knowledge management for competitive advantage. The electronic journal of knowledge management, $3(2)$, p. 75 .

Hansen, M. T., Nohria, N., \& Tierney, T. (1999). What's your strategy for managing knowledge? Harvard Business Review, 106-116.

Harlow, H. (2008), "The effect of tacit knowledge on firm performance", Journal of Knowledge Management, Vol. 12 No. 1, pp. 148-163.

Herrgard, T.H. (2000). "Difficulties in the diffusion of tacit knowledge in organizations", Journal of Intellectual Capital, Vol. 1 No. 4, pp. 357-65.

Hooley, G. J., Greenley, G. E., Cadogan, J. W. \& Fahy, J. (2005). The performance impact of marketing resources. Journal of Business Research, 58(1), 18-27.

Howells, J. (1996). Tacit knowledge. Technology analysis \& strategic management, 8(2), pp.91-106.

Hunt, S. D. (2000). A general theory of competition: Resources, competences, productivity, economic growth. Thousand Oaks, CA: Sage 
Johnson, W. (2007). "Mechanisms of tacit knowing: pattern recognition and synthesis", Journal of Knowledge Management, Vol. 11 No. 4, pp. 123-39.

Kamoche, K. (1996). 'Strategic Human Resource Management within a Resource-capability View of the Firm', Journal of Management Studies, 33: 213-33.

Kenyon, G.N. \& Sen, K.C. (2015). Creating a Competitive Advantage. In The Perception of Quality (pp. 5-12). Springer London.

King, W.R. (2009). Knowledge management and organizational learning (pp. 3-13). Springer US.

Kirk, J. and Miller, M.L., 1986. Reliability and validity in qualitative research. Sage.

Kogut, B. \& Zander, U. (1992). Knowledge of the firm, combinative capabilities and the replication of technology. Organisation Science, 3, 383-397.

Kogut, B., \& Zander, U. (1992). Knowledge of the firm, combinative capabilities, and the replication of technology. Organization Science, 3: 383-397.

Kruger, C.J. and Johnson, R.D., 2011. Is there a correlation between knowledge management maturity and organizational performance? Vine, 41(3), pp.265-295.

Lado, A. \& Wilson, M. (1994) 'Human Resource System and Sustained Competitive Advantage: Competency-based Perspective', Academy of Management Review, 19: 699- 727.

Lecuona, J.R. \& Reitzig, M. (2014), “Knowledge worth having in 'excess': the value of tacit and firm-specific human resource slack”, Strategic Management Journal, Vol. 35 No. 7, p. 954.

Lee, S.H., Phan, P.H. \& Chan, E. (2005). The impact of HR configuration on firm performance in Singapore: a resource-based explanation. The International Journal of Human Resource Management, 16(9), pp.1740-1758.

Lin, C.P. (2007). To share or not to share: Modeling tacit knowledge sharing, its mediators and antecedents. Journal of business ethics, 70(4), pp.411-428.

Lubit, R. (2001). The keys to sustainable competitive advantage. Organizational Dynamics, 29(3), pp.164-178.

Mahdi, O.R., Almsafir, M.K. and Yao, L., 2011. The role of knowledge and knowledge management in sustaining competitive advantage within organizations: A review. African Journal of Business Management, 5(23), pp.9912-9931.

McCann, J.E. III \& Buckner, M. (2004), "Strategically integrating knowledge management initiatives", Journal of Knowledge Management, Vol. 8 No. 1, pp. 47-63.

McKelvey, (1983). Organizational Systematics: Taxonomy. Evolution And Classification. Berkeley, CA: University of California Press. 
Michalisin, M.D., Smith, R.D. \& Kline, D.M. (1997), "In search of strategic assets", The International Journal of Organizational Analysis, Vol. 5, pp. 360-87.

Miles, M.B., Huberman, A.M. and Saldaña, J., 2014. Qualitative data analysis: A methods sourcebook. 3rd.

Mosconi, E. \& Roy, M.C. (2013). Linking knowledge management and organizational performance. International Business Research, 6(9), p.68.

Muthuveloo, R., Shanmugam, N. and Teoh, A.P., 2017. The impact of tacit knowledge management on organizational performance: Evidence from Malaysia. Asia Pacific Management Review, 22(4), pp.192-201.

Nahapiet, J., \& Ghoshal, S. (1998). Social capital, intellectual capital, and the organizational advantage. Academy of Management Review, 23: 242-266

Nath, P., Nachiappan, S. \& Ramanathan, R. (2010). The impact of marketing capability, operations capability and diversification strategy on performance: A resource-based view. Industrial Marketing Management, 39(2), pp.317-329.

Nonaka, I. (1998), The Knowledge Creating Company, Harward Business Review on Knowledge Management, USA, pp. 21-46.

Nonaka, I. \& Takeuchi, H. (1995), The Knowledge-creating Company: How Japanese Companies Create the Dynamics of Innovation, Oxford University Press, New York, NY.

Nonaka, I. \& Takeuchi, H. (2004), Theory of organisational knowledge creation, in Takeuchi, H. and Nonaka, I. (Eds), Hitotsubashi on Knowledge Management, Wiley, Singapore.

Nonaka, I., Konno, N. \& Toyama, R. (2000), “Emergence of Ba”, in Nonaka, I. and Nishiguchi, T. (Eds), Knowledge Emergence: Social, Technical and Evolutionary Dimensions of Knowledge Creation, Oxford University Press, Oxford

Nonaka, I., Toyama, R. \& Byosiere, P. (2003), “A theory of organization knowledge creation: understanding the dynamic process of creating knowledge' ', in Dierkes, M., Antal, A.B., Child, J. and Nonaka, I. (Eds), Handbook of Organizational Learning and Knowledge, Oxford University Press, Oxford, pp. 491-517.

Olaniran, O. J., Love, P. E. D., Edwards, D. J., Olatunji, O., \& Matthews, J. (2015a). Chaotic dynamics of cost overruns in oil and gas megaprojects: A review. International Journal of Civil, Environmental, Structural, Construction and Architectural Engineering, 9(7), 856- 862.

Pathirage, C.P., Amaratunga, D.G. and Haigh, R.P. (2007). Tacit knowledge and organisational performance: Construction industry perspective. Journal of knowledge management, 11(1), pp.115-126.

Patton, M.Q., 2002. Qualitative research and evaluation methods. $3^{\text {rd }}$ ed. Newbury Park, CA: Sages. 
Peteraf, M.A. (1993). 'The Cornerstone of the Competitive Advantage: A Resource-based View'. Strategic Management Journal, 14: 179-91.

Pfeffer, J. (1994). Competitive advantage through people. California management review, 36(2), pp.9-28.

Polanyi, M. (1958). Personal Knowledge: Towards a Post-critical Philosophy, Routledge \& Kegan Paul Ltd, London.

Polanyi, M. (1966). The tacit dimension. Gloucester, MA: Peter Smith.

Prahalad, C.K. (1983). 'Developing Strategic Capability: An Agenda for Top Management', Human Resource Management, 22: 237-54.

Ranucci, R.A. \& Souder, D. (2015). Facilitating tacit knowledge transfer: routine compatibility, trustworthiness, and integration in M \& As. Journal of Knowledge Management, 19(2), pp.257-276.

Rosemann, M. \& vom Brocke, J. (2015). The six core elements of business process management. In Handbook on business process management 1 (pp. 105-122). Springer Berlin Heidelberg.

Rumelt, R. P. (1984). Towards a strategic theory of the firm. In R. B. Lamb (Ed.), Competitive strategic management: 556-570. Englewood Cliffs, NJ: Prentice-Hall.

Saa-Perez, P.D. \& Garcia-Falcon, J.M. (2002). A resource-based view of human resource management and organizational capabilities development. International Journal of Human Resource Management, 13(1), pp.123-140.

Semeon, G., Garfield, M. \& Meshesha, M. (2015). Exploring Mechanisms in Tacit Knowledge Externalization: Preliminary Findings from Participatory Agricultural Innovation Practices in Ethiopia.

Sharkie, R. (2003). Knowledge Creation and its place in the development of sustainable competitive advantage, Journal of Knowledge Management, Vol.7, no.1, pp.20-31.

Song, D. (2009). The tacit knowledge-sharing strategy analysis in the project work. International Business Research, 2(1), p.83.

Song, M., Benedetto, A. D., \& Nason, R. W. (2007). Capabilities and financial performance: The moderating effect of strategic type. Journal of the Academy of Marketing Science, 35, $18-34$.

Spender, J. C. (1996). Making knowledge the basis of a dynamic theory of the firm. Strategic Management Journal, 17 (Winter Special Issue), 45-62.

Spender, J.C. \& Scherer, A.G. (2007). The philosophical foundations of knowledge management: Editors' introduction. Organization 2007; 14; 5 DOI: $10.1177 / 1350508407071858$ 
Tantalo, C. \& Priem, R.L. (2016). Value creation through stakeholder synergy. Strategic Management Journal, 37(2), pp.314-329.

Teece, D. J., Pisano, G. \& Shuen, A. (1997). Dynamic capabilities and strategic management. Strategic Management Journal, 18(7), 509-533.

Teerajetgul, W. \& Chareonngam, C. (2008), "Tacit knowledge utilization in Thai construction projects', Journal of Knowledge Management, Vol. 12 No. 1, pp. 164-74.

Tsai, M. T., \& Li, Y. H. (2007). Knowledge creation process in new venture strategy and performance. Journal of Business Research, 60(4), 371-381

Tsai, M.T. \& Li, Y.H. (2007). Knowledge creation process in new venture strategy and performance. Journal of Business Research, 60(4), pp.371-381.

Ulrich, D. (1991). Using human resources for competitive advantage. In R. Kilmann, I. Kilmann, and Associates (Eds.) Making Organizations Competitive. San Francisco, CA: Jossey-Bass.

Ulrich, D. (1997). Human Resource Champions, Boston, MA: Harvard Business School Press.

van den Berg, H.A. (2013). Three shapes of organisational knowledge. Journal of Knowledge Management, 17(2), pp.159-174.

Wernerfelt, B. (1984). A resource-based view of the firm. Strategic Management Journal, 5: 171-180.

Wittmann, C. M., Hunt, S. D., \& Arnett, D. B. (2009). Explaining alliance success: Competences, resources, relational factors, and resource-advantage theory. Industrial Marketing Management, 38(7), 743-756.

Wong, K.Y. \& Aspinwall, E. (2006). Development of a knowledge management initiative and system: A case study. Expert Systems with Applications, 30(4), pp.633-641.

Wright, P. M., Dunford, B. B., \& Snell, S. A. (2001). Human resources and the resource-based view of the firm. Journal of Management, 27: 701-721.

Wright, P.M., McMahan, G.C. \& McWilliams, A. (1994) 'Human Resources and Sustained Competitive Advantage: A Resource-based Perspective', International Journal of Human Resource Management, 5: 301-26.

Wright, P.M., McMahan, G.C., McCormick, B. \& Sherman, W.A. (1998) 'Strategy, Core Competence, and HR Involvement as Determinants of HR Effectiveness and Refinery Performance', Human Resource Management, 37: 17-29.

Zaim, H., Gürcan, Ö.F., Tarım, M., Zaim, S. \& Alpkan, L. (2015). Determining the critical factors of tacit knowledge in service industry in Turkey. Procedia-Social and Behavioral Sciences, 207, pp.759-767. 


\section{List of Table(s)}

Table 1: Characteristic of research participants

\begin{tabular}{|l|l|c|c|}
\hline & & Number & Percentage \% \\
\hline \multirow{3}{*}{ Age } & $40-45$ & 2 & 40 \\
\cline { 2 - 4 } & $46-50$ & 2 & 40 \\
\cline { 2 - 4 } & $51-55$ & 1 & 20 \\
\hline \multirow{3}{*}{ Gender } & Female & 2 & 40 \\
\cline { 2 - 4 } $\begin{array}{l}\text { Education/ } \\
\text { qualification }\end{array}$ & $\begin{array}{l}\text { Masters with 1 professional } \\
\text { qualification }\end{array}$ & 3 & 60 \\
\cline { 2 - 4 } $\begin{array}{l}\text { Masters with more than 1 } \\
\text { Years } \\
\text { experience }\end{array}$ & $\begin{array}{l}\text { of } \\
\text { of }\end{array}$ & 2 & 60 \\
\cline { 2 - 4 } & $16-20$ & 2 & 40 \\
\cline { 2 - 4 } & $21-25$ & 1 & 40 \\
\hline
\end{tabular}

\section{List of Figures}


Figure 1: Conceptual framework (authors generated)

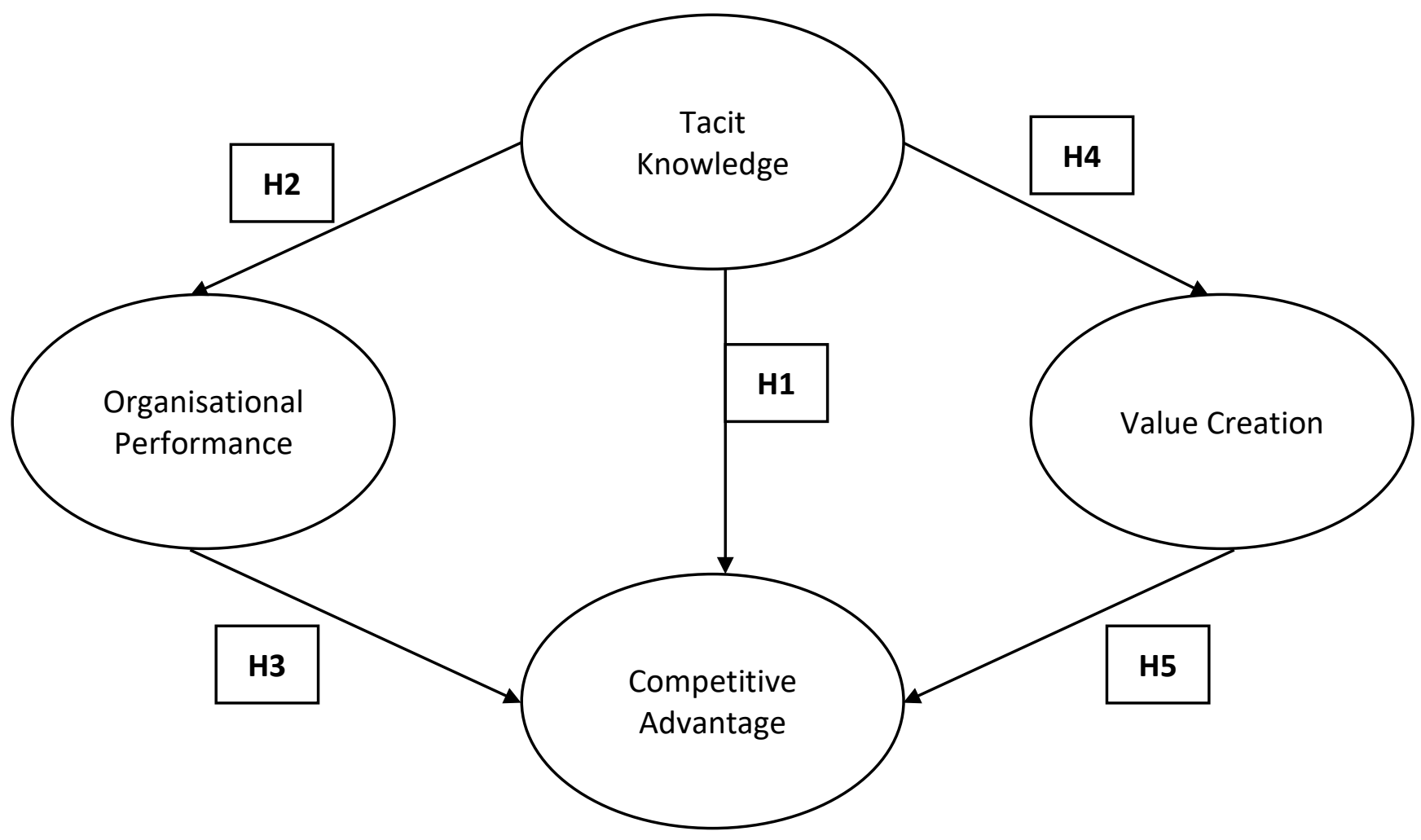

Figure 2: Research findings

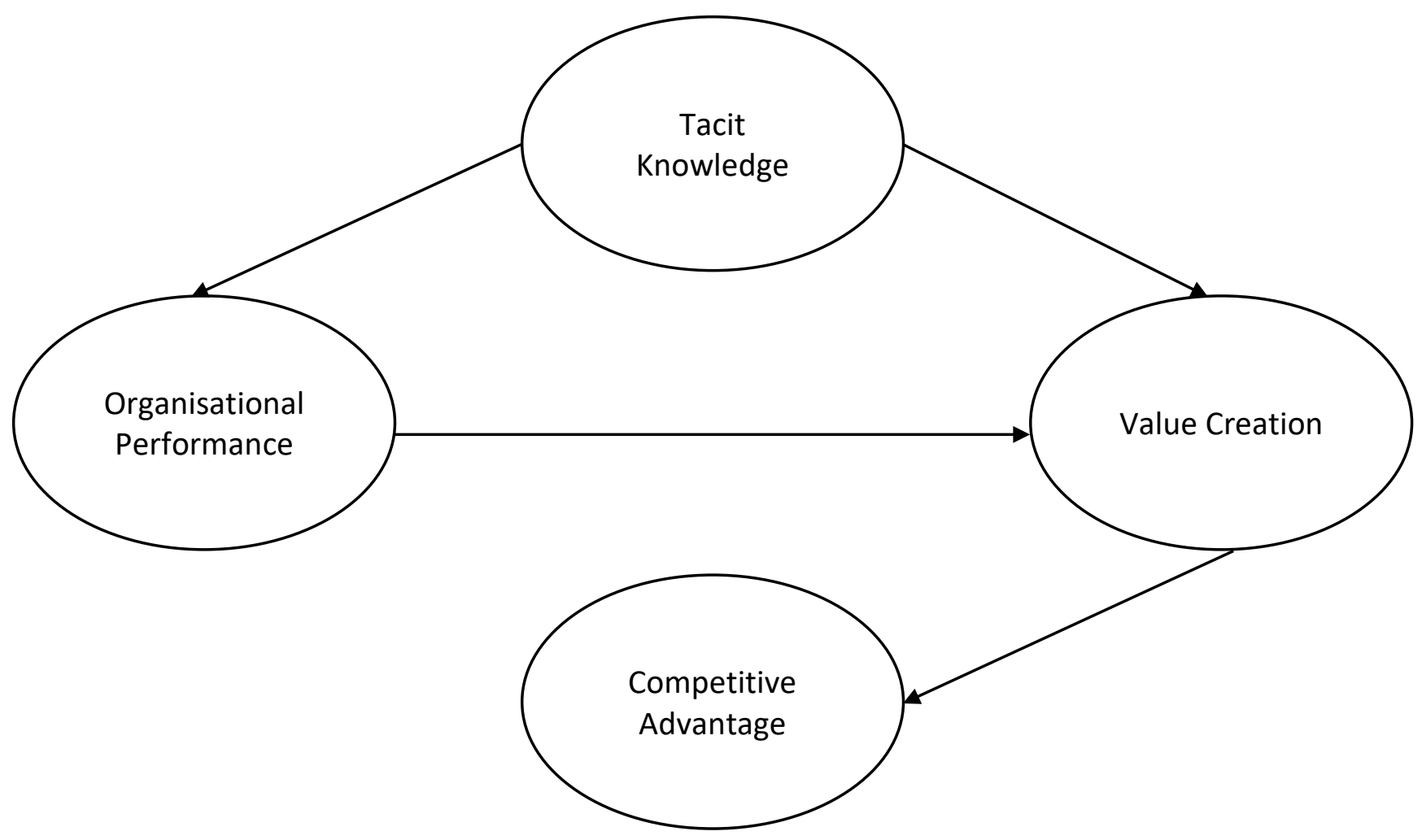

